\title{
SPECIAL MAP BASE OF MILITARY GEOINFORMATION SYSTEM
}

\author{
${ }^{1}$ Ilgar MUSAYEV,${ }^{2}$ Magsad GOJAMANOV \\ ${ }^{1}$ Azercosmos Open Joint Stock Company, Space Images Processing Department, AZ 1000 Baku, Azerbaijan \\ ${ }^{2}$ Baku State University, Department of Geodesy and Cartography, AZ 1148 Baku, Azerbaijan \\ 1ilqar-refiler@rambler.ru, ${ }^{2}$ mgodja@yandex.ru
}

(Geliş/Received: 30.11.2018; Kabul/Accepted in Revised Form: 21.12.2018)

\begin{abstract}
Since its inception, the Geographic Information System (GIS) has been widely used in many areas of the civilian sector. However, this system with its remarkable technical capabilities is still insufficiently implemented in the military sphere. Therefore, the article points out the necessity and expediency of creating a GIS for military purposes.

When creating a GIS for military purposes, it should enrich its main block, that is, a topographic database (TDB) with additional materials such as special maps, aerospace photo documents that are universally used in the troops.Based on these considerations, the article proposes to create in the military GIS an additional functional unit called the "Special Map Base". This article describes in detail the structure, content and function of the proposed block.
\end{abstract}

Key Words: Military geoinformation system, geospatial database, topographic database, special maps, photo documents

\section{Tematik Harita Tabanlı Askeri Coğrafi Bilgi Sistemi}

ÖZ: Kuruluşundan bu yana, Coğrafi Bilgi Sistemi (CBS) sivil sektörün birçok alanında yaygın olarak kullanılmaktadır. Ancak, bu teknik, olağanüstü teknik yetenekleri ile askeri alanda hala yetersiz bir şekilde uygulanmaktadır. Bu nedenle, makale askeri amaçlar için bir CBS yaratmanın gerekliliği ve yararına işaret etmektedir.

Askeri amaçlar için bir CBS oluştururken, ana bloğunu, yani, özel haritalar, uzay gemilerinde evrensel olarak kullanılan uzay fotoğraf belgeleri gibi ek materyalleri içeren bir topografik veritabanı (TDB) zenginleştirmelidir. Askeri CBS'de "Ö̈zel Harita Tabanı" adı verilen ek bir fonksiyonel birim oluşturmayı önerir. Bu makalede, önerilen bloğun yapısı, içeriği ve işlevi ayrıntılı olarak açılanmaktadır.

Anahtar Kelimeler: Askeri coğrafi bilgi sistemi, coğrafi veri tabanı, topografik veri tabanı, özel haritalar, fotoğraf belgeler

\section{INTRODUCTION}

Before proceeding to the content of a special map base of military GIS (MGIS), we will briefly review the features of a standard GIS.

Depending on the area of implementation, the content of GIS is determined in different ways. In some definitions, it appears as a tool for creating maps, storaging, using and displaying of geographic data, and in others as a computer geographic database to support decision making: 
Geographic Information System - this is a computer system of cartographic software, created by individuals, scientific organizations and industrial enterprises for the collection, analysis, storing and dissemination of information from the Earth's surface (Chrisman, 1986).

Geographic information system - this is a computer system for the collection, storage, processing, analysis and presentation of geographic data by specific organizations (Clarke, 1986).

Geographic information system is a set of powerful tools for collecting, storing, processing, transforming and demonstrating geographic data (Burroogh, 1986).

A geographic information system is a decision support system using geospatial data (Geoffrey, et al., 1990).

Summarizing these definitions, we can say that in general, GIS is a system for collecting, analyzing, systemizing, processing, storing, presenting and managing all geographic and geospatial data on the Earth using computer technology.

Geographical information system was first used by the Canadian government in the 60s of the last century for the purpose of inventorying state land plots. Since that time, GIS has been widely used by state institutions and private companies in other countries as a "Tool" for planning the production process, making decisions and managing them (Musayev, 2006).

Thanks to the technical capabilities of GIS, military organizations also have showed interest in creating GIS for military purposes. Military organizations are well aware and appreciate that GIS in its format is a large geographic database that provides detailed information about the terrain in the form of digital raster and vector topographic maps, or on separate layers of maps and map products. Such a database is very important for the proper planning and conduct of operational-tactical acts in military affairs. If the GIS base is additionally equipped with military information, this system will be called the Military Geographic Information System (MGIS) or the Defense Geographic Information System (DGIS).

Depending on the purpose of creating and assigning tasks, technical equipment, software, level and scope of application, the MGIS may have different structures. However, for all types ofGIS, the four main functional blocks - 1. Topographic database block; 2. Technologyblock; 3. Hardware block and 4. Software block are characteristic.

\section{TOPOGRAPHIC DATABASE OF THE GEOGRAPHIC INFORMATION SYSTEM}

The variants for creating GIS are determined by their purpose, tasks and responsibilities, resulting from these tasks. TDBisthemainfunctionalblockofGIS.This block contains all the geographic information of the system, as indicated above.In recent years, special computer programs allow to collect geographic data from maps and aerospace images directly into the TDB.

The main advantage of TDB in comparison with a topographic map is, that here the presented geographic data makes possible to conduct a complex analysis of the terrain in the current time (realtime).TDB is also an effective tool for creating and updating digital topographic and thematic maps.If the analogue (paper) topographic maps represent the geographic content of the terrain (relief, vegetation, hydrography, settlements, socio-cultural objects, road network, boundaries, etc.) with cartographic simbols, but the TDB on the basis of the spreadsheet of attributes allowsand provide more detailed information about each object of the map.Due to the preservation of data in a vector format, using TDBs, you can quickly update maps and map products.

Because the database objects are in the form of simbols, their places can be changed, erased, updated, enlarged as images or displayed as a 3D model.The TDB has the ability to present the previous state of objects and events, as well as the future (predictive).

For the functioning of GIS, as well as MGIS, including the collection and presentation of information in TDB, it is advisable to use cartographic software Oracle, ArcCIS and Global Mapper.The Oracle software is a powerful computer program and is recommended for use in the implementation of the MGIS server.Database management capacity in the Oracle software is $100 \div 1000$ GB (gigabytes).The program allows thousands of users at the same time to access the TDB of the MGIS.At the present time 
Oracle7, Oracle 10 and Oracle 11 are used in production.ArcCIS software is used to collect map data in TDB, as well as to create map layers.A Global Mapper as a GIS software package is used to represent digital cartographic products.

\section{DISTINCTION BETWEEN GEOSPATIAL AND GEOINFORMATION SYSTEMS}

The twentieth century marks the era of the scientific and technological revolution, aviation, space and nuclear technologies.The 21st century is called the age of information.In everyday life we everywhere meet with information.

Information - this is a data about a particular object or reality (Dzhabrailova, 2017). It should be noted that $80-85 \%$ of the information available everywhere is geo-information. Geospatial information is a combination of different types of information about space, territory, events and processes.The terms "geospatial", "geospatial data", "geospatial database" are included in the technical literature in the late 80 s of the last century and are now widely used in scientific literature.

Despite the differences in essence and designation in most cases, the term "Geospatial Data Base" (GDB) is used in place of the term "Geographic Information System".This is a completely wrong approach.

GDB - is designed to store, process and represent objects in a geometric space.The basis for GDB is the geospatial information network, which is called a Geospatial dataset (GDS). In GDB geospatial data are stored in the form of coordinates, addresses, city names and codes.

Unlike GDB, the GIS is based on a topographic database, which consists of geographic information, topographic maps, topographic plans, aerospace images and other materials.

A comparative analysis between GDB and GIS shows that it is more expedient to use GIS for military purposes.Because, at present time, military operations are mainly planned and conducted using digital topographic maps and map productswhich are stored in the TDB of MGIS.

\section{SPECIAL MAP BASE OF MILITARY GEOINFORMATION SYSTEM}

When creating a GIS, depending on the content and purpose, you can include additional elements in its structure. As we know, when planning and carrying out military operations, alongside topographic maps, there are widely used special maps and aerospace images in the troops (note: further in the text"Special maps").

The main purpose of creating special maps is to provide troops with additional terrain data not available on topographic maps.Depending on the tasks, if special maps are created, it is necessary to digitize and collect them into a separate database in order not to confuse them with other maps (Fugure 1). Thus, with the use of modern cartographic computer software such as ArcGIS, it is possible to create a new special map base for military GIS. 


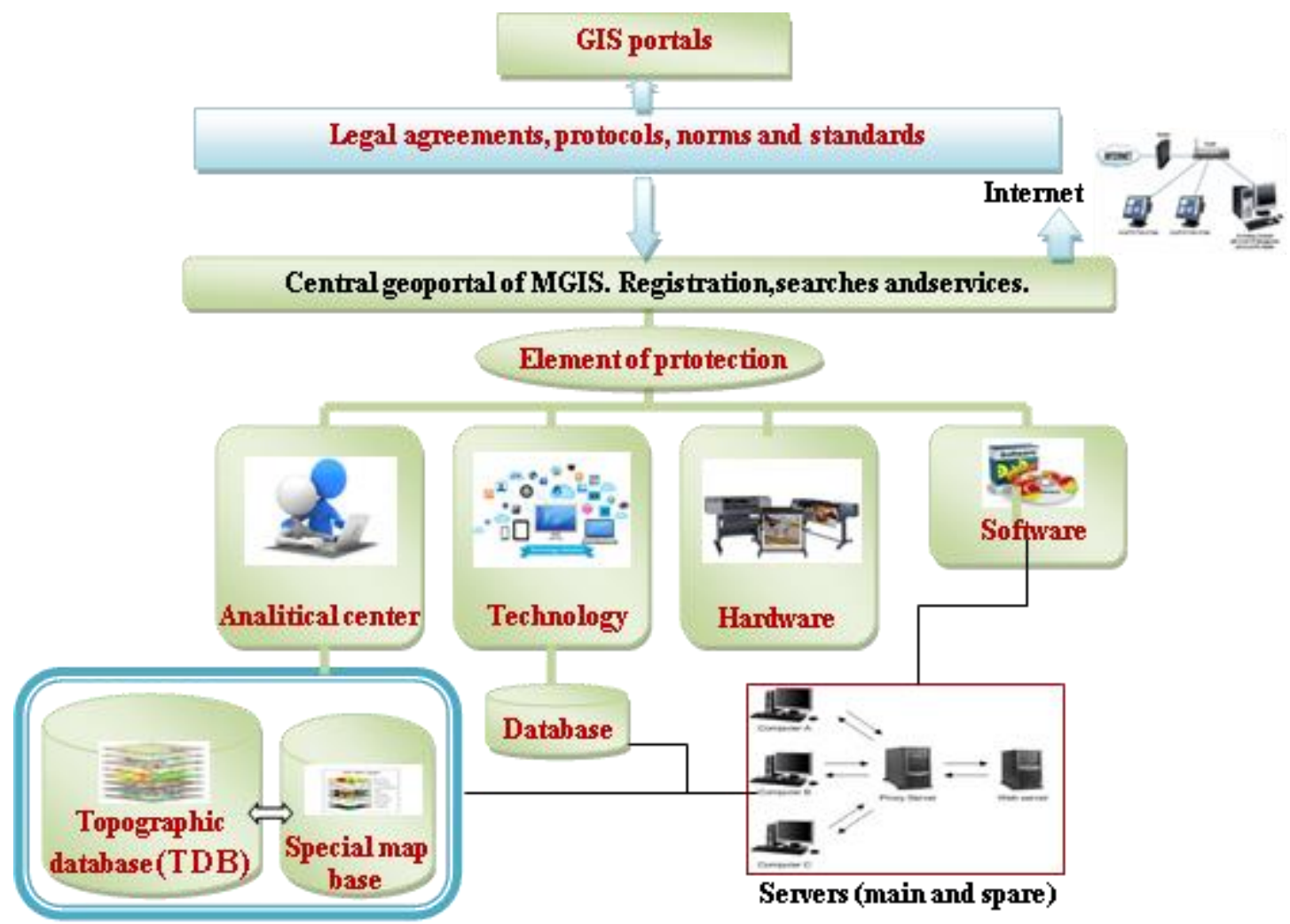

Figure 1. MGIS functional blocks (variant)

After determining the content of special maps, we will review their types and appointments, as well as aerospace images located in a special military GIS database.

\section{SPECIAL MAPS}

Special maps -are maps that describe in detail the specific part of the terrain depending on the task and the requirements of higher combat headquarters. They are created in advance by units and units of the topographic service of the Army in the preparation and conduct of military operations.

When creating special maps, in detail analyze the data of territorial intelligence obtained from various cartographic sources (Qovoruxin and Qamezo, 1968). After that, all these data are displayed in a vector format as a separate "Shape" file, if necessary, the created shapefile or vector layer is combined with a raster topographic map and printed.

Special maps include: maps of terrain changes (Figure 2); maps of contour points (maps of geodetic data); maps of river sections; cross-country maps; maps of mountain passages; maps of landing areas; maps of aboveground and underground water sources; maps of drainage systems;maps of plant cover;nautical charts;relief maps; maps of railways; road maps; aerodrome maps; maps of seaports; maps of accommodation centers; maps of energy centers; oil storage maps; geological maps; hypsometric maps, etc. (A guide to phototopographic work in the field of topogeodetic support of troops, 1983).

Of the above-mentioned special maps, the first four are most often used in the troops. 


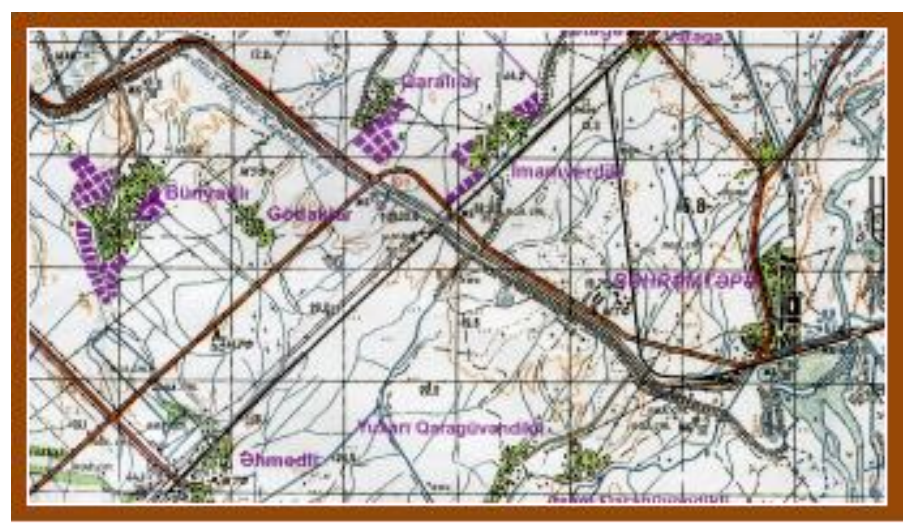

Figure 2. Map of terrain changes (fragment)

Operative correction of topographic maps produsing faster than updating them. When conducting military operations, a great need is shown for them, they are more effective and are used by troops everywhere.

\section{AEROSPACE PHOTO DOCUMENTS}

Aerospace photo documents are intended to bring the information about the terrain to the headquarters and troops in addition to the information available on topographic maps. Like special maps, they are also created on the most important areas of battlefilds. These documents usually show decrypted data about the enemy.

In headquarters, photo documents are usually used together with topographic maps (Mikailov, 2016). Photo documents include:

aerospace images;

photo schemes;

photo plans (orthophoto);

photo maps, etc.

Special maps and photo documents must satisfy the requirements of the troops for the completeness, reliability, accuracy and visibility of the images of elements and objects of the terrain on them, as well as the timing of the creation and visualization of these documents.

\section{CONCLUSIONS AND RECOMMENDATIONS}

In order to improve the troops daily activities, increase the efficiency and effectiveness of planning and conducting military operations, military GIS as an information base is an indispensable tool in military affairs.

Topographic database is one of the main block of the standard GIS and differs significantly from other types of geographic data base. Therefore, its creation requires a special approach.

The experience of past warriors, military operations conducted in modern conditions and military trainings shows that for making informed decisions it is necessary to have additional sources of data that are not available on topographic maps.

In this regard, it is required to provide troops with special maps and photo documents. We suggest that MGIS of the Army which will be created, be supplemented with a new block which called "Special map base". The newly created database of special maps, enabling the enrichment of TDB with special geographic information, and will also enhance the military significance of GIS. 


\section{REFERENCES}

A Guide to Phototopographic Work in The Field of Topogeodetic Support of Troops, 1983, Part 3. Creation of Originals of Special Maps and Photo Documents about The Terrain, Moscow, pp. 3

Burroogh, P., 1986, Principles of Geographic Information Systems for Resources, Publisher Oxford University press (paperback) (193 pp) ISBN 019854592 4. https://onlinelibrary.wiley.com/doi/abs/ p. 1

Chrisman, N., 1986, Exploring Geographic Information Systems, https://trove.nla.gov.au/work/ p. 12

Clarke, K., 1986, Geographic Information Systems and Environmental Modeling, https://www.amazon.com/Geographic-Information-Systems-Environmental-Modeling/dp/. University of California. p. 1

Dzhabrailova, Z., 2017, Database. Knowledge base. Expert system: - Institute of Information Technology of the National Academy of Sciences of Azerbaijan. Collection of reports, p. 6

Geoffrey, E., David, C., Halkard, M., Design and Implementation of a Spatial Decision Support System for Site Selection, Columbia, 1990-9pp.

http://proceedings.esri.com/library/userconf/proc95/to100/p100.html, University of South Carolina. p.1

Mikailov, K., 2016, Military Topography, Baku, pp. 198

Musayev, I., 2006, "Digital Mapping Technology and Geographic Information Systems", Journal of military Knowledge, 2006, No. 5. pp. 21-32.

Qovoruxin, A., Qamezo, M., 1968, Directory of The Officer for Military Topograph, Moscow, pp. 39 